\title{
STUTZELIASTROBUS BOHEMICUS COMB. NOV. - BASAL CUPRESSACEAE CONIFER FROM THE CENOMANIAN OF THE BOHEMIAN CRETACEOUS BASIN, CENTRAL EUROPE
}

\author{
JIŘí KVAČEK ${ }^{1, *},{ }^{2}$ ZUZANA HEŘMANOVÁ ${ }^{1}$, JANA BRUTHANSOVÁ ${ }^{1}, J^{\prime}$ AKUB KARCH ${ }^{2,3}$, JAN ŽEMLIČKA ${ }^{2}$, \\ JAN DUDÁK ${ }^{2,3}$ \\ ${ }^{1}$ National Museum, Prague, Václavské náměstí 68, 11000 Praha 1, the Czech Republic; e-mail: jiri_kvacek@nm.cz, \\ zuzka.hermanova@gmail.com, jana_bruthansova@nm.cz. \\ ${ }^{2}$ Institute of Experimental and Applied Physics, Czech Technical University in Prague, Horská 3a/22, 12800 Praha 2, the Czech Republic; \\ e-mail: jakub.karch@utef.cvut.cz, jan.zemlicka@utef.cvut.cz,jan.dudak@cvut.cz. \\ ${ }^{3}$ Faculty of Biomedical Engineering, Czech Technical University in Prague, nám. Sítná 3105, 27200 Kladno, the Czech Republic. \\ * corresponding author
}

Kvaček, J., Heřmanová, Z., Bruthansová, J., Karch, J., Žemlička, J., Dudák, J. (2018): Stutzeliastrobus bohemicus comb. nov. basal Cupressaceae conifer from the Cenomanian of the Bohemian Cretaceous Basin, Central Europe. - Fossil Imprint, 74(1-2): 179-188, Praha. ISSN 2533-4050 (print), ISSN 2533-4069 (on-line).

\begin{abstract}
The Cupressaceae conifer Stutzeliastrobus bohemicus (BAYER) J.KVAČEK comb. nov. is described from the Cenomanian Peruc-Korycany Formation of the Bohemian Cretaceous Basin. It is characterised by elongate ovuliferous cones with helically arranged thin, bilaterally symmetrical ovuliferous bract-scale complexes, bearing two to four winged elongate ovoid seeds per bract-scale complex. Ovuliferous cones are found attached to twigs of Cyparissidium-type shoots, showing amphistomatic scale-like leaves with an adaxial cuticle, bearing two stomatal bands with transversely or obliquely orientated monocyclic to amphicyclic stomata. The abaxial cuticle shows monocyclic to amphicyclic stomata scattered irregularly in the basal part of the leaf. The lectotype is compressed, but the 3D preserved lignified specimen, studied using X-ray microtomography, revealed its internal structure. It is compared to Stutzeliastrobus foliatus F.HerRera et al. from the Early Cretaceous of Mongolia, differing in morphology of its bract-scale complexes. The thin ovuliferous cone scales complexes of S. bohemicus bearing two to four winged seeds per cone scale argue for its relationship with Taiwanioideae, the basal subfamily of Cupressaceae.
\end{abstract}

Key words: Stutzeliastrobus, Taiwanioideae, ovuliferous cone, foliage, Cenomanian, Late Cretaceous, X-ray microtomography

Received: June 19, 2018 | Accepted: July 1, 2018 | Issued: August 31, 2018

\section{Introduction}

The diversity of Mesozoic Cupressaceae is large and new species are continually being discovered. Particularly the Cretaceous period represents a time of rapid evolution of this family (Stockey et al. in Farjon 2005). The rich and diverse fossil record of Cupressaceae from the Jurassic to the Late Cretaceous provides excellent documentation of this process (e.g. Harris 1943, 1979, Escapa et al. 2008, Rothwell et al. 2011, Shi et al. 2014). Mesozoic ovuliferous cones consisting of foliate, dorsoventrally flattened, helically arranged bract-scale complexes bearing a variable number of inverted ovules are characteristic for earlydiverging clades of the family (Farjon 2005, Schulz and Stützel 2007). As a result of evolutionary studies by Gadek et al. (2000) based on molecular approach, conifers bearing this type of ovuliferous cone represent relatives of two relict subfamilies Cunninghamioideae and Taiwanioideae. The extant subfamily Cunninghamioideae is represented by Cunninghamia, with two species known from China to Vietnam and Laos (Farjon 2003, 2005). Taiwanioideae is monotypic, with one genus Taiwania occurring on the island of Taiwan and several localities in China, Myanmar and Vietnam (Farjon and Ortiz-Garcia 2003, Farjon 2005).

As already mentioned, cupressaceous conifers with affinities to Cunninghamioideae and Taiwanioideae are well represented in the fossil record. The first representatives of this group (Elatides) appear in the Middle Jurassic (Harris 1943, 1979); similar fossils are known from the Late Jurassic of Scotland (Van Konijnenburg-van Cittert and van der Burgh 1989, Rothwell et al. 2011, Spencer et al. 2015), Early Cretaceous of Canada (Rothwell et al. 2011, Atkinson et al. 2014a, b) and Late Cretaceous of Japan (Ohana and Kimura 1995). Fossil Taiwanioideae are known already 
from the Early Jurassic of Argentina (Escapa et al. 2008), the Late Jurassic of China (Zhang et al. 2012) and the Early Cretaceous of Mongolia (Herrera et al. 2017). The Late Cretaceous saw their gradual decline (Nishida et al. 1992).

The Peruc Flora of the Bohemian Cretaceous Basin is rich in fossil remains of cupressoid conifers, particularly from the subfamily Sequoideae (Kvaček 1997, 1999b, 2014, 2015). However, conifers of basal subfamilies of Cupressaceae had not previously been recorded there. In this paper, beside the compressed material, we present a microCT study of a partly lignified ovuliferous basal Cupressaceae cone on a twig. MicroCT studies revealed a number of characters, including details of ovuliferous cone morphology, and arrangement of its cone-scales and seeds, and allowed reinterpretation of the conifer already described by Bayer $(1914,1920)$ as Cyparissidium bohemicum. Our study indicates its affinities to Taiwanioideae, although there are characters different from Taiwania, e.g. the higher number of seeds per cone-scale.

\section{Material and methods}

The fossil plant material is derived from dark coaly mudstone, part of the freshwater Peruc Member of the Peruc-Korycany Formation (Bayer 1914, 1920) of the Bohemian Cretaceous Basin, as defined by Čech (Čech et al. 1980, Čech 2011). The studied material occurs in a plant association consisting of pteridophytes - Nathorstia sp., Gleichenia fricii, one undescribed sequoioid conifer (interpreted by Bayer $(1914,1920)$ as Sequoia sp.) and angiosperm foliage Myrtoidea geinitzii (HEER) J.KVAČEK et GREGUŠ.

The locality was discovered in 1901 by Josef Borufka, a teacher at the local school, and his wife. They gave the material to Edvin Bayer for his studies (Bayer 1914, 1920). All the studied material is housed in the collections of the National Museum, Prague (NM).

Lignified twigs were sampled by needle and cleaned in HF. After careful washing in water, the material was dried. Fragments of twigs were studied using an Olympus SZX 12 binocular microscope. Selected material was documented by SEM. Fragments were mounted on SEM stubs using nail polish, and observed in a Hitachi xS-3700N scanning electron microscope. Some fragments were used for cuticle analysis. After maceration with Schulze's reagent $\left(\mathrm{HNO}_{3}+\mathrm{KClO}_{3}\right)$ and neutralisation in water, the fragments were treated in a low concentration solution of $\mathrm{KOH}$, which was used for washing out the oxidized coal matter. The time for oxidation was about 30-45 minutes. After chemical treatment, the cuticles were washed in distilled water in Petri dishes. For light microscopy, cuticles were embedded in glycerine and framed with nail polish. Cuticle preparations were studied and documented in a Olympus BX50 light microscope, using Nomarski DIC. The lectotype was observed in two microCT laboratories: Institute of Experimental and Applied Physics CTU (IEAP) and Centre of excellence Telč (CET). A detailed micro-radiography was made at IEAP using a WIDEPIX $_{10 \times 5}$ large area pixel counting detector (Jakůbek et al. 2014), assembled from 50 Timepix chips with full sensitive area of $14.3 \times 7.15 \mathrm{~cm}^{2}(2560 \times 1280$ pixels, $55 \mu \mathrm{m}$ pixel pitch $)$ and micro-focus X-ray source Hamamatsu L8601-01 with $5 \mu \mathrm{m}$ spot size. The final micro-tomography of F2746 was held at CET. The TORATOM device for micro-tomography uses the Perkin Elmer XRD 1622 AP14 flat panel detector with $200 \mu \mathrm{m}$ pixel pitch and total pixel resolution $2048 \times 2048$. The XWT 240 SE X-ray tube with focal spot $\sim 4 \mu \mathrm{m}$ was used as a beam source. Acquisition parameters: tube voltage $190 \mathrm{kV}$, target current $284 \mu \mathrm{A}, 1200$ projections, total acquisition time $2.2 \mathrm{~s}$, factor of magnification 3 , full angle cone beam $\mathrm{CT}$. The tomography was reconstructed with VG Studio Max 3.1 using FBP CT reconstruction module. The resulted model of F2746 has $66 \mu \mathrm{m}$ voxel size. Gathered data were analysed and visualised using N-Recon and Avizo 9.1.1. software.

Nomenclatural novelties and other nomenclatural acts are being registered in the Plant Fossil Names Registry, which is hosted and operated by the National Museum, Prague for the International Organisation of Palaeobotany (IOP), each with a unique registry number.

\section{Systematic palaeobotany}

\section{Order Pinales Gorozhankin, 1904 Family Cupressaceae GraY, 1821}

\section{Stutzeliastrobus F.Herrera, Shi, P.Knopf, B.L.Andrew, IChinn., M.TaKahashi et Herend., 2017}

Ty p e : Stutzeliastrobus foliatus F.HerRera et al., 2017, p. 27 , figs $3-10$.

Discussion. The genus Stutzeliastrobus described from the Early Cretaceous of Mongolia (Herrera et al. 2017) is based on well-preserved ovuliferous cones borne on Cyparissidiumtype twigs. Ovuliferous cones of Stutzeliastrobus are characterised by having thin, bilaterally symmetrical, bract-scale complexes bearing two to four winged seeds per cone scale complex. Its leaves are amphistomatic with the abaxial side showing stomata only in basal part. These characters are very similar to the studied material described by Bayer under the genus Cyparissidium (Bayer 1914, 1920).

The most basal extant taxa of Cupressaceae, Cunninghamia and Taiwania, and Athrotaxis selaginoides (Gadek et al. 2000, Farjon and Ortiz-Garcia 2003, Farjon 2005, Schulz and Stützel 2007) share many similarities with Stutzeliastrobus. All have helically arranged needle-like leaves and terminal ovuliferous cones with a large number of helically arranged bract-scale complexes (where bract has dominant position) bearing seeds that are inverted at maturity (Farjon 2005, Schulz and Stützel 2007). Stutzeliastrobus differs from Cunninghamia in having a variable number (24) seeds per bract-scale complex, winged seeds and imbricate leaves. It differs from Taiwania in having more than two seeds per cone scale. Taiwania is similar to Stutzeliastrobus in having the ovuliferous scale having built predominantly by a bract (forming a bract-scale complex) and being very flat with an imbricate arrangement. Athrotaxis selaginoides differs from Stutzeliastrobus in having a thicker and more elaborate bract-scale complex with terminal ligule-like scale. These characters place Stutzeliastrobus close to the basal monogeneric subfamily Taiwanioideae (Herrera et al. 2017). 

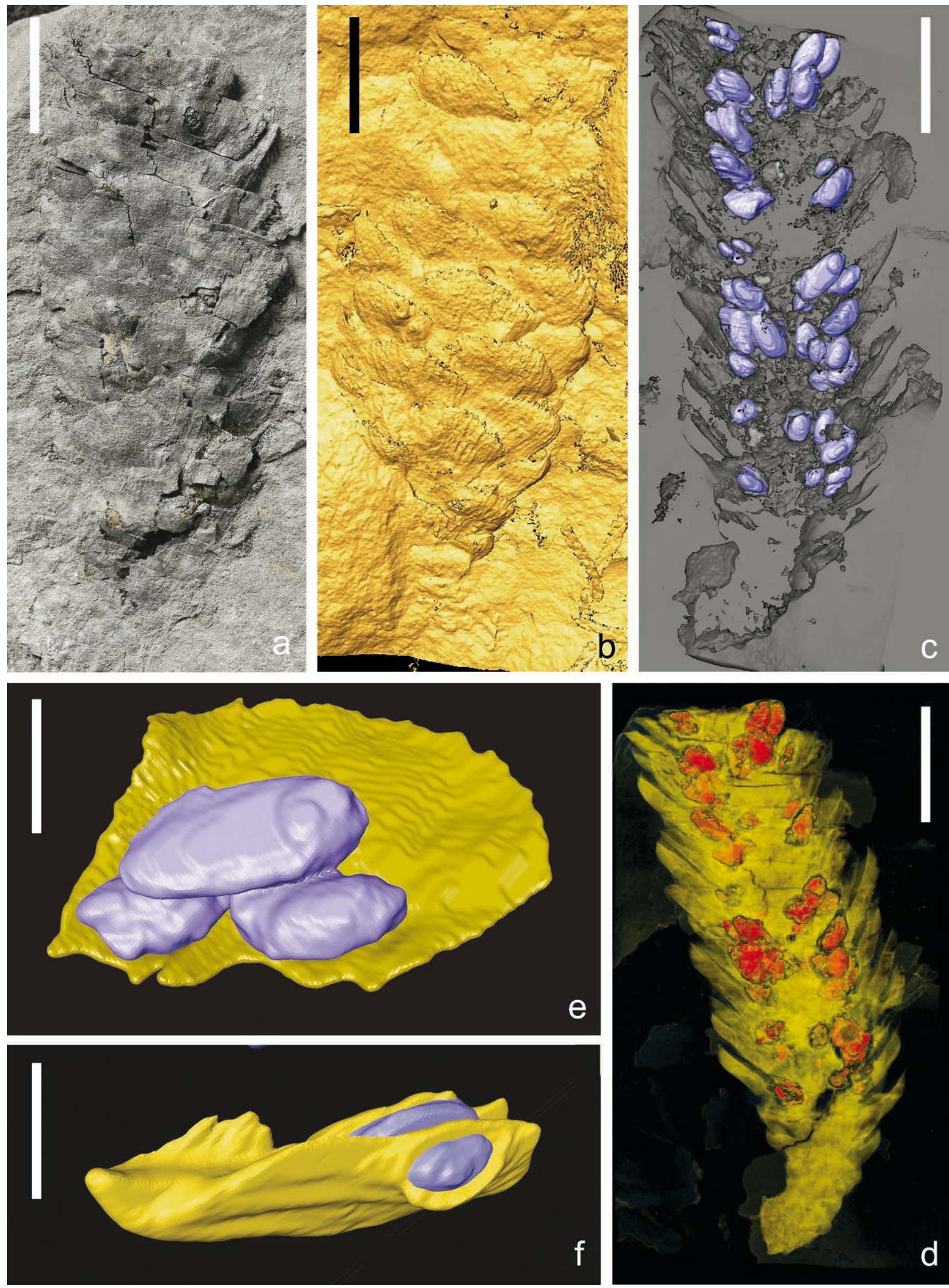

Text-fig. 1. Stutzeliastrobus bohemicus (BAYER) J.KVAČEK, No. NM-F 2746, Harcov, lectotype. a - surface view of ovuliferous cone photograph, scale bar $10 \mathrm{~mm}, \mathrm{~b}$ - microCT isosurface of ovuliferous cone, scale bar $10 \mathrm{~mm}, \mathrm{c}$ - microCT longitudinal section of ovuliferous cone with segmented seeds, scale bar $10 \mathrm{~mm}, \mathbf{d}$ - microCT longitudinal section of ovuliferous cone in yellow, seeds in red, e - 3D visualised bract-scale complex bearing three seeds, adaxial view, scale bar $2.5 \mathrm{~mm}, \mathrm{f}-3 \mathrm{D}$ visualised bract-scale complex bearing two seeds, lateral view (incomplete reconstruction of the scale visualises the front seed), scale bar $2.5 \mathrm{~mm}$. 


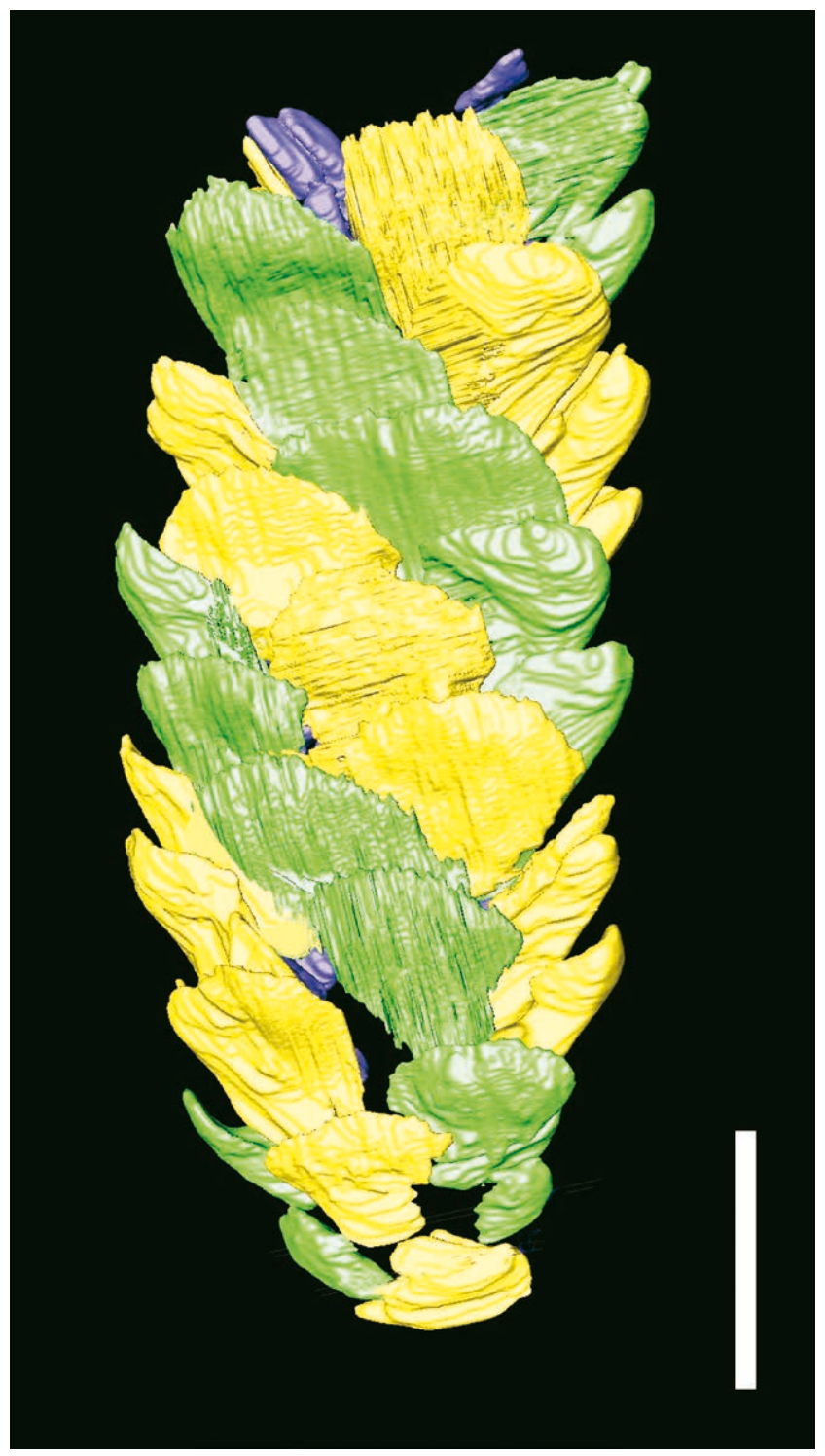

Text-fig. 2. Stutzeliastrobus bohemicus (BAYER) J.KVAČEK, No. NM-F 2746, Avizo reconstruction showing ovuliferous cone with helically arranged bract-scale complexes (green and yellow) and seeds (blue), scale bar $10 \mathrm{~mm}$.

Stutzeliastrobus bohemicus (BAYER) J.KVAČEK comb. nov. Text-figs 1-5

B a s i o n y m. Cyparissidium bohemicum BAYER 1914, Archiv pro přírodovědecké prozkoumání Čech, 15(5), p. 43, text-figs 21-23.

1914 Cyparissidium bohemicum BAYER, p. 43, text-figs 21-23.

1920 Cyparissidium bohemicum BAYER; Bayer, p. 50, text-figs 21-23.

1968 Cyparissidium bohemicum BAYER; Němejc, p. 393, text-fig. 301a, pl. 38, fig. 4.

L e c t o t y p e. NM-F 2746, designated here in, Text-figs 1a-f, 2, 3a, c-f, housed in the National Museum, Prague.

Plant Fossil Names Registry Number. PFN000138 for new combination; PFN000140 for lectotype designation.

Type locality. Harcov near Dvůr Králové n. Labem, the Czech Republic.
Type horizon. Cretaceous, Cenomanian, Peruc Korycany Formation.

Em e n d e d diagnos is . Elongate ovuliferous cones born terminally on twigs. Ovuliferous cones consisting of about 60 helically arranged imbricate bract-scale complexes. Each bract-scale complex simple, thin, flat, bilaterally symmetrical, delicately ribbed, with base narrowing, cuneate, entire-margined, apex obovate, irregularly delicately dentate, terminating with a mucro. There are two or three inverted seeds per cone scale. Seeds are elliptical, ovoid, sometimes asymmetrical, with distal wing. Sterile twigs with helically arranged rhomboidal, imbricated Cyparissidium - type leaves with obtuse apex and delicate abaxial keel, appressed to stem. Leaves amphistomatic, adaxial cuticle bearing two stomatal bands with transversely or obliquely orientated monocyclic to amphicyclic stomata surrounded by 4-6 subsidiary cells, ordinary epidermal cells elongate; abaxial cuticle bearing monocyclic to amphicyclic stomata scattered irregularly in basal part of leaf, ordinary epidermal cells isodiametric. Hypodermis strongly cutinised.

Material studied. NM-F 864, F 872, F 877, F 875a, b, F 1414, F 2742, F 2744, F 2840, F 4551.

D e s c r i p t i o n . Reproductive structures. The lectotype (Text-figs 1a-d, 2, 3a, c-f) is a fragment of basal and medial parts of an ovuliferous cone $45 \mathrm{~mm}$ long and $25 \mathrm{~mm}$ broad. It is born on a twig and represents the best preserved specimen, being lignified, partly coalified and 3D preserved. It consists of more than 60 helically arranged bract-scale complexes (Text-figs 1b, 2). Text-fig. 1a shows external surface of the ovuliferous cone, while Text-figs 1b, 2 display the cone surface buried in sediment. Each bract-scale complex is deltoid, having an entire-margined cuneate base (Text-fig. $1 \mathrm{e}, \mathrm{f}$ ) and oblong ovate apex with delicate teeth and terminal mucro. Text-fig. 3a shows the basal part of the adaxial surface of the bract-scale complex with centrally placed thickened stalk (arrow). The abaxial surface of the bractscale complex is delicately ribbed (Text-fig. 1b). MicroCT study revealed numerous morphological and anatomical details used for the emended diagnosis, particularly the arrangement of seeds (Text-figs 1e, f, 3c-e). The seeds are arranged in the basal part of the bract-scale complexes (Text-figs 1e, f, 3a), typically two or three (Text-fig. 1e, f). The mature seeds (Text-fig. 3d, e) are ovoid, 5-5.6 mm long and 3-3.2 mm broad; immature seeds (Text-fig. 3b, f) are smaller, 3-3.5 $\mathrm{mm}$ long and $2-2.5 \mathrm{~mm}$ broad. The wing is arranged in the distal part (Text-fig. 3b, c, e).

The specimens figured in Bayer (1914: figs 21a, b, 22a, 23a; 1920: figs 21a, b, 22a, 23a) are not so well preserved; they are mostly impressions of external cone surfaces (Text-fig. 3a). Specimen No. NM-F 4551 (Bayer 1914: fig. 21a) shows a basal part of a cone $(60 \times 30 \mathrm{~mm})$, showing an impression of its external surface (Text-fig. 4a), with fragments of lignified deltoid bracts-scale complexes 10-11× 5-7 $\mathrm{mm}$ in size. One of them has a preserved terminal part with a well-preserved mucro (Text-fig. 4a, arrow).

Specimen NM-F 872 (Bayer 1914: fig. 21b; 1920: fig. 21b) display a twig $60 \mathrm{~mm}$ long, $2 \mathrm{~mm}$ broad, with two branchlets and terminally born ovuliferous cone $(36 \times$ $6 \mathrm{~mm}$; Text-fig. 4b). The branchlets, angled off at $30^{\circ}$, are 



Text-fig. 3. Stutzeliastrobus bohemicus (BAYER) J.KvAčEK, Harcov. a - surface view of bract-scale complex (arrow) and probably aborted seed, No. NM-F 2746 (lectotype), scale bar 1 mm, b - seed with a wing (arrow) NM-F 872, scale bar 1 mm, c- microCT perpendicular section of bract scale complex showing two seeds with wings (arrows), No. NM-F 2746 (lectotype), scale bar $1 \mathrm{~mm}, \mathrm{~d}$ - microCT longitudinal section of bract scale complex showing three seeds, No. NM-F 2746 (lectotype), scale bar $1 \mathrm{~mm}$, e - microCT longitudinal section of bract scale complex with one seed reconstructed showing micropyle (arrow), No. NM-F 2746 (lectotype), scale bar $1 \mathrm{~mm}, \mathrm{f}$ - isolated seed with a fragment of wing (arrow), No. NM-F 2746 (lectotype), scale bar 1 mm. 

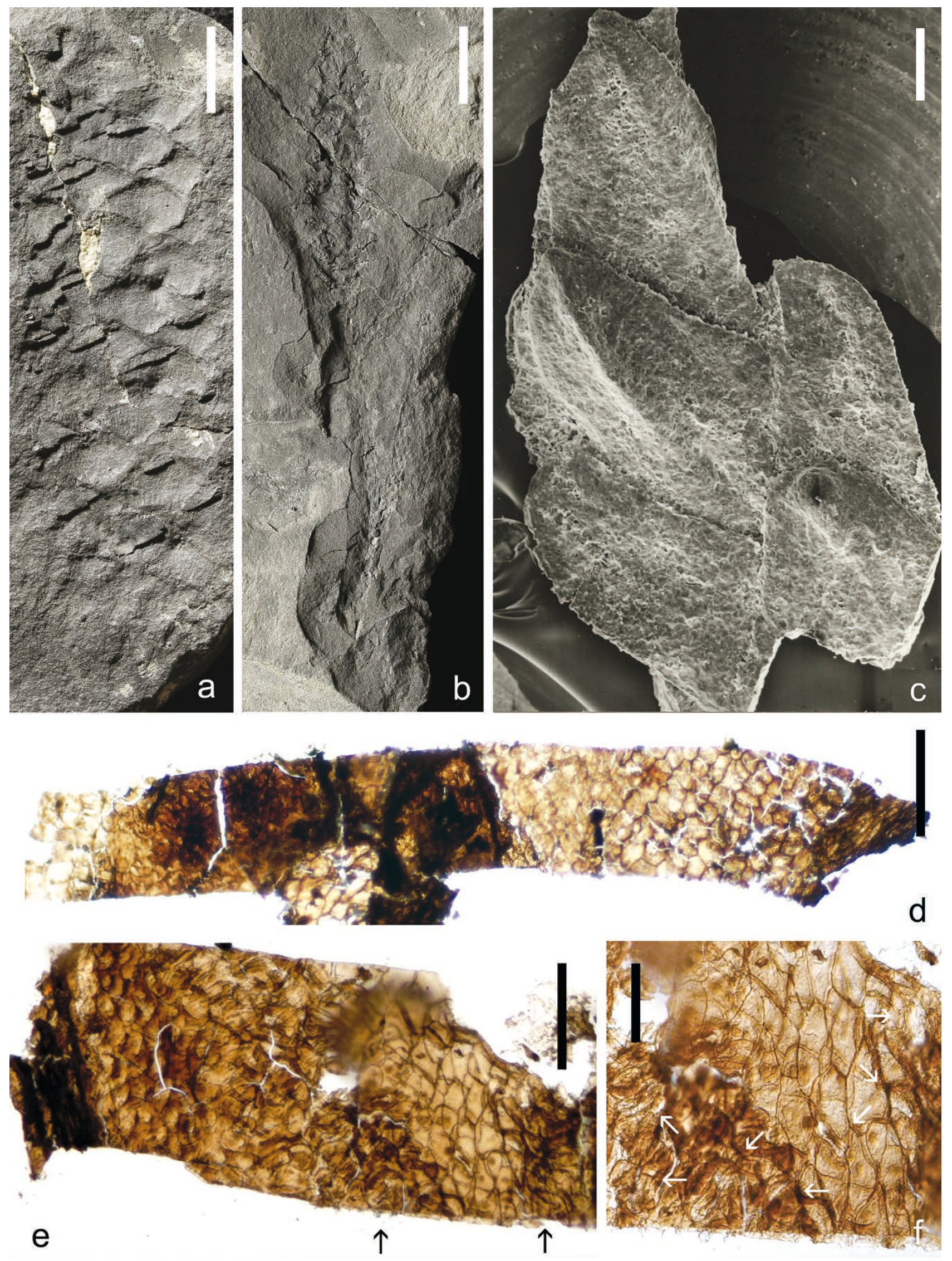

Text-fig. 4. Stutzeliastrobus bohemicus (BAYER) J.KVAČEK, Harcov. a - ovuliferous cone showing apical parts of bract-scale complexes, NM-F 4551, scale bar 10 mm, b - shoot with attached ovuliferous cone (Bayer 1914: fig. 21b; 1920: fig. 21b), NM-F 872, scale bar $1 \mathrm{~mm}$, c - SEM of isolated shoot, NM-F 2840, scale bar $0.5 \mathrm{~mm}$, d - LM of abaxial cuticle and hypodermis, NM-F 872b, scale bar $200 \mu \mathrm{m}, \mathrm{e}-\mathrm{LM}$ of abaxial cuticle showing two stomatal bands (arrows) and hypodermis, NM-F $872 \mathrm{~b}$, scale bar 100 $\mu \mathrm{m}, \mathrm{f}-\mathrm{LM}$ of abaxial cuticle, detail of e showing stomata (arrows), NM-F 872b, scale bar $50 \mu \mathrm{m}$. 

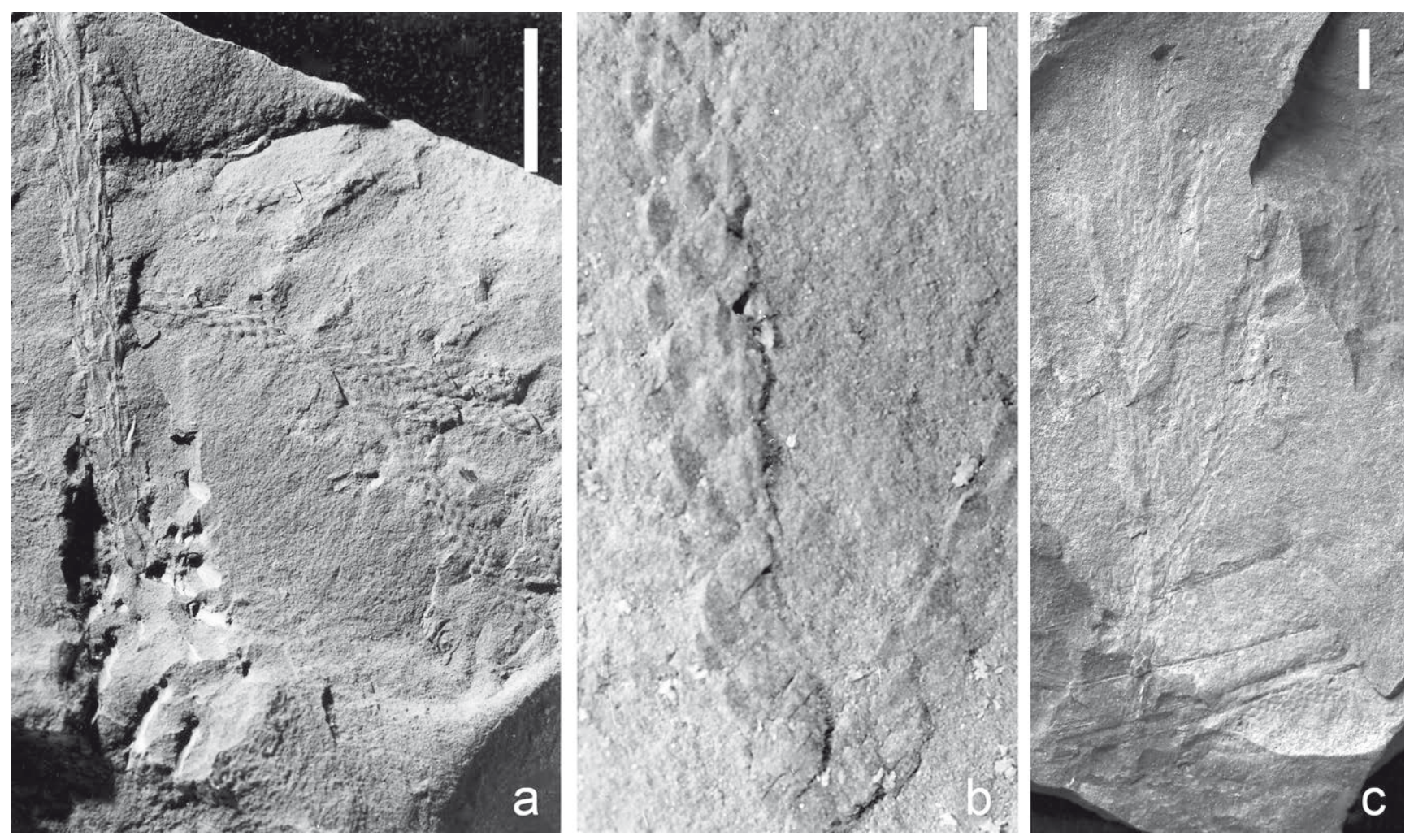

Text-fig. 5. Stutzeliastrobus bohemicus (BAYER) J.KvačEK, Harcov. a - Shoots of various thickness, NM-F 875 (Bayer 1914: fig. 22c, d; 1920: fig. 22c, d), scale bar $10 \mathrm{~mm}$, b - detail of branch showing imbricate rhomboidal leaves, NM-F 2744, scale bar 2 mm, c branched twig, NM-F 877 (Bayer 1914: fig. 21c; 1920: fig. 21c), scale bar 10 mm.

30 and $35 \mathrm{~mm}$ long. The ovuliferous cone $(8 \times 35 \mathrm{~mm})$ is longitudinally broken, bearing helically arranged bractscale complexes. Its cone-scales are smaller $(4 \times 6 \mathrm{~mm})$ and arranged helically, some showing winged seeds (Text-fig. $3 b)$.

Sterile foliage. Fragments of branches are preserved as leaf compressions (Text-figs 4, 5a-c). The most complete branch was figured by Bayer (1914: fig. 21c; 1920: fig. 21c; No. NM-F 877), showing leaves rhomboidal, keeled, amphistomatic (Text-fig. 5f). Helically arranged leaves are small ( $0.8 \mathrm{~mm}$ broad, $1-0.8 \mathrm{~mm}$ long), appressed to the axis (Text-fig. 5c).

The adaxial cuticle is thinner than the abaxial cuticle (Text-fig. 5d), it shows two stomatal bands $80-150 \mu \mathrm{m}$ wide (Text-fig. 5e). Ordinary epidermal cells $(10-25 \times 25-45 \mu \mathrm{m})$ are elongate to polygonal, with straight anticlinal walls. Monocyclic to amphicyclic stomata with well-cutinized guard cells are sunken in oval pits surrounded by 4-6 unspecialized subsidiary cells $(10-25 \times 25-40 \mu \mathrm{m})$ (Textfig. 5f). They are orientated transversely or obliquely to the leaf margin (Text-fig. 5d). The hypodermis is cutinized, and it was difficult to remove its remnants from the preparation. The abaxial cuticle is thicker than the adaxial, and shows only few stomata (Text-fig. 4d); ordinary cells are quadrangular, nearly isodiametric $(25-40 \times 35-80 \mu \mathrm{m})$ with straight or bent anticlinal walls (Text-fig. 4f). Fresh material collected in the locality by JK in 1997 was used for SEM studies (NM-F 2840) and further cuticle preparations (NM-F 2747). It shows details of a leafy shoot (Text-fig. 4c). Basal parts of leaves are covered by irregularly scattered oval pits that probably represent stomata.
Discussion. Fossil remains of this conifer were collected and described by Bayer $(1914,1920)$ who assigned them to the genus Cyparissidium, based particularly on observations of foliage. MicroCT studies of the wellpreserved specimen, suggested here as a lectotype, allowed a more accurate interpretation of the ovuliferous cone and twig, and a better description of its anatomy. Based on this new data, we were able to compare the cone with previously described taxa with well-preserved anatomy, rather than with only compressed specimens. The comparison mentioned in the discussion to the genus resulted in a new interpretation of this conifer, and its transfer to the recently described genus Stutzeliastrobus.

Stutzeliastrobus bohemicus differs from S. foliatus F.HERRERA et al., 2017 in having ribbed cone-bract complexes, delicately toothed in their terminal parts, and large ovoid seeds.

Foliage of Stutzeliastrobus bohemicus is very similar in appearance to Cyparissidium gracile (HeER) HeER from the Cretaceous of Greenland (Heer 1868: pl. 43, figs. 1e, 3c; Heer 1874: pl. 17, fig. 5b, c, pl. 18, fig. 6b, pl. 19, figs $1-11$, pl. 20, fig. 1e, pl. 21, figs 9b, 10d). The type specimens stored in Naturhistoriska riksmuseet, Stockholm, were sampled for cuticle analysis, but without success. The best cuticle preparations were obtained from non-figured material (S 087443), the locality of Ekkofrat. The cuticle pattern of both taxa is also very similar. The type material of $C$. gracile yields only one incomplete ovuliferous cone (S 87438, S 105123, part and counterpart - Heer 1874: pl. 19 , figs $8,9 \mathrm{~b}$ ), which is poorly preserved, so it is difficult to compare it with $S$. bohemicus. 
As already mentioned by Harris (1979), the species C. gracile, although used as the type of the genus, shows characters of the broadly defined genus Brachyphyllum. The same problem existed with the species $C$. bohemicum. This problem for the Czech material is now solved, due to the well-preserved lectotype, which allowed its transfer to the genus Stutzeliastrobus.

The leaves of Stutzeliastrobus bohemicus resemble those of Taiwania, showing similar morphology and micromorphology of epidermis: mature leaves of Taiwania are shortly decurrent, keeled, amphistomatic and appressed to the stem (Farjon 2005).

From other fossil cupressoid conifers, Stutzeliastrobus bohemicus is most similar to Cunninghamiostrobus yubariensis STOPES et FuJI from the Late Cretaceous of Japan (Ohana and Kimura 1995). Stutzeliastrobus bohemicus differs from Cunninghamiostrobus yubariensis in having rhombic flat, non-peltate bract-scale complex, but lacking adaxial socket-like cavities and pronounced interseminal ridges.

Another similar fossil conifer genus, Austrohamia, contains two species: Austrohamia minuta EsCAPA, CúNEO et Axsmith from the Early Jurassic of Argentina (Escapa et al. 2008: fig. 11O) and Austrohamia acanthobractea J.Wei Zhang, D'Rozario, L.I.Wang, Y.Li et J.Yao from the Middle - Late Jurassic of China (Zhang et al. 2012). They both have bract-scale complexes similar to Stutzeliastrobus bohemicus, but differ in having only one or two seeds per bract-scale complex (Herrera et al. 2017).

Juvenile cone scale complexes Athrotaxites stockeyi EscApA et al., 2016 (Escapa et al. 2016) from the Late Cretaceous of USA have a similar number of seeds per scale complex (3-4), but differ from Stutzeliastrobus bohemicus in having an ovuliferous cone scale complex already robustly thick in the juvenile stage.

Parataiwania nihongii M.Nishida et al. from the Late Cretaceous of Japan (Nishida et al. 1992) differs from $S$. bohemicus in having a thicker bract-scale complex of ligulelike shape, more like Cunninghamia.

Compression/impression material of Taiwania cryptomeroides described from the Early Cretaceous to Pliocene localities of Siberia, Japan and Alaska is discussed and summarised by LePage (2009). The paper documents the probable existence of the taxon in Alaska since the Late Cretaceous, but due to the poor preservation of the fossil plant material, particularly ovuliferous cones, this assumption remains open until better material becomes available. The same is true for ovuliferous cones and twigs of Taiwania schaefleri SCHLOEMER-JÄGER described from the Palaeocene of Svalbard (Schloemer-Jäger 1958, Budancev and Golovneva 2009).

\section{Remarks on palaeoenvironment}

Reconstruction of the palaeoenvironment as mesophytic coniferous forests dominated by $S$. bohemicus is based on the morphology of $S$. bohemicus shoots. The shoots are covered by small rhomboidal imbricate leaves sheathed with quite thick cuticle. The presence of the xerophytic fern Nathorstia (Kvaček and Dašková 2007, 2010) and the absence of typical flood plain and swamp elements in the material collected from the Harcov locality provide another argument for interpreting $S$. bohemicus as a slope, upland plant. Occurrence of Stutzeliastrobus bohemicus in the Peruc-Korycany provides another example of Early Cretaceous/Jurassic relict being present in the Peruc Flora. This is similar to what has already been observed in other localities hosting mesophytic Early Cretaceous elements, such as Nilssonia, Sagenopteris, Nilssoniopteris, Zamites (Kvaček 1994, 1995, 1999a, Knobloch and Kvaček 1997). Their occurrence documents environmental stability of habitats of pre-Alpine Central Europe during the Cretaceous.

\section{Conclusions}

Stutzeliastrobus bohemicus is described as the first taiwanioid conifer from the Cenomanian Peruc Flora of the Bohemian Cretaceous Basin. It shows a number of similarities with Stutzeliastrobus foliolatus from the Early Cretaceous of Mongolia, including the same morphology of the bract-scale complex, number of seeds per bract-scale complex and general cuticle pattern. However, it differs in details of its bract-scale complex and stomatal distribution on abaxial cuticle. In terms of phytogeography, S. bohemicus represents a distant relative of $S$. foliolatus, suggesting survival of this genus in pre-Alpine Central Europe through the Cenomanian.

\section{Acknowledgements}

We are grateful to Jaromír Váňa and Jan Bubník (NM) for preparation of the samples, Lenka Váchová (NM) for photo-documentation of the material and Petr Daneš for English editing. This work was financially supported by Ministry of Culture of the Czech Republic (DKRVO 2018/05 National Museum, 00023272) and from European Regional Development Fund-Project "Engineering applications of microworld physics" (No. CZ.02.1.01/0.0/0.0/16_019/000 0766).

\section{References}

Atkinson, B. A., Rothwell, G. W., Stockey, R. A. (2014a): Hubbardiastrobus cunninghamioides gen. et sp. nov., evidence for a Lower Cretaceous diversification of cunninghamioid Cupressaceae. - International Journal of Plant Sciences, 175: 256-269.

https://doi.org/10.1086/674318

Atkinson, B. A., Rothwell, G. W., Stockey, R. A. (2014b): Hughmillerites vancouverensis sp. nov. and the Cretaceous diversification of Cupressaceae. - American Journal of Botany. 101: 2136-2147.

https://doi.org/10.3732/ajb.1400369

Bayer, E. (1914): Fytopaleontologické příspěvky ku poznání českých kř́idových vrstev peruckých [Phytopalaeontological contributions to knowledge of the Peruc Member (Bohemian Cretaceous)]. - Archiv pro př́rodovědecké prozkoumání Čech, 15(5): 1-66. (in Czech)

Bayer, E. (1920): Phytopalaeontologische Beiträge zur Kenntnis der Perucer Kreideschichten in Böhmen. - 
Archiv der naturwisschenschaftlichen Landesdurchforschung von Böhmen, 15(5): 1-78.

Budancev, L., Y., Golovneva, L. B. (2009): Iskopaemye flory Arktiki. II - Paleogenovaya flora Shpitsbergena [Fossil flora of Arctic. II - Paleogene flora of Spitzbergen]. - Marafon, Sankt Peterburg, 400 pp. (in Russian with English summary)

Čech, S. (2011): Palaeogeography and stratigraphy of the Bohemian Cretaceous Basin (Czech Republic) - an overview. - Geologické výzkumy na Moravě a ve Slezsku, 18(1): 18-21.

Čech, S., Klein, V., Kř́iž, J., Valečka, J. (1980): Revision of the Upper Cretaceous stratigraphy of the Bohemian Cretaceous Basin. - Věstník Ústředního ústavu geologického, 55(5): 277-296.

Escapa, I. H., Cúneo, R., Axsmith, B. (2008): A new genus of the Cupressaceae (sensu lato) from the Jurassic of Patagonia: implications for conifer megasporangiate cone homologies. - Review of Palaeobotany and Palynology, 151: $110-122$.

https://doi.org/10.1016/j.revpalbo.2008.03.002

Escapa, I. H., Gandolfo, M. A., Crebet, W. L. Nixon, K. C. (2016). A new species of Athrotaxites (Athrotaxoideae, Cupressaceae) from the Upper Cretaceous Raritan Formation, New Jersey, USA. - Botany, 94(9): 231-245. https://doi.org/10.1139/cjb-2016-0061

Farjon, A. (2005): A monograph of Cupressaceae and Sciadopitys. - Royal Botanic Gardens, Kew, 643 pp.

Farjon, A., Ortiz-Garcia, S. (2003): Cone and ovule development in Cunninghamia and Taiwania (Cupressaceae sensu lato) and its significance for conifer evolution. American Journal of Botany, 90: 8-16. https://doi.org/10.3732/ajb.90.1.8

Gadek, P. A., Alpers, D. L., Heslewood, M. M., Quinn, C. J. (2000): Relationships within Cupressaceae sensu lato: a combined morphological and molecular approach. American Journal of Botany, 87: 1044-1057. https://doi.org/10.2307/2657004

Harris, T. M. (1943): The fossil conifer Elatides williamsoni. - Annals of Botany, 7: 325-339. https://doi.org/10.1093/oxfordjournals.aob.a088542

Harris, T. M. (1979): The Yorkshire Jurassic flora. V. Coniferales. - British Museum of Natural History, London, $166 \mathrm{pp}$.

Heer, O. (1868): Flora fossilis arctica, Die fossile Flora der Polarländer enthaltende die in Nordgrönland, auf der Melville-Insel, im Banksland, am Mackenzie, in Island und in Spitzbergen entdeckten fossilen Pflanzen. - F. Schulthess, Zürich, $192 \mathrm{pp}$.

Heer, O. (1874): Die Kreide-Flora der arktischen Zone, gegründet auf die von den schwedischen Expeditionen von 1870 und 1872 in Grönland und Spitzbergen gesammelten Pflanzen. - Kungliga Svenska Vetenskaps-akademiens Handlingar, 12(6): 1-138.

Herrera, F., Shi, G., Knopf, P., Leslie, A. B., Ichinnorov, N., Takahashi, M., Herendeen, P. S. (2017): Cupressaceae conifers from the early cretaceous of Mongolia. - International Journal of Plant Sciences, 178(1): 19-41. https://doi.org/10.1086/689577

Jakůbek, J., Jakůbek, M., Platkevič, M., Soukup, P., Tureček, D., Sýkora, V., Vavř́k, D. (2014): Large area pixel detec- tor WIDEPIX with full area sensitivity composed of 100 timepix assemblies with edgeless sensors. - Journal of Instrumentation, 9: C04018.

https://doi.org/10.1088/1748-0221/9/04/C04018

Knobloch, E., Kvaček, J. (1997): Bennettitalean and coniferalean (?) leaves from the Cretaceous (Cenomanian) of the Bohemian Massif, Central Europe. - Cretaceous Research, 18: 567-586. https://doi.org/10.1006/cres.1997.0074

Kvaček, J. (1994): Nilsonia and Nilsonia-like leaves from the Cenomanian of Bohemia. - Acta Universitatis Carolinae, Geologica, 1992(1-2): 63-71.

Kvaček, J. (1995): Cycadales and Bennettitales leaf compressions of the Bohemian Cenomanian, Central Europe. - Review of Palaeobotany and Palynology, 84: 389-412. https://doi.org/10.1016/0034-6667(94)00093-Y

Kvaček, J. (1997): Sphenolepis pecinovensis sp. nov. a new taxodiaceous conifer from the Bohemian Cenomanian. Mededeelingen van 's Rijks Geologischen Dienst, Haarlem, 58: 121-128.

Kvaček, J. (1999a): New data and revision of three gymnosperms from the Cenomanian of Bohemia-Sagenopteris variabilis (VELENOVSKÝ) VELENOVSKÝ, Mesenea bohemica (CORDA) comb. n. and Eretmophyllum obtusum (VELENOVSKÝ) comb. n. - Sborník Národního muzea v Praze, řada B - Př́rodní vědy, 55(1-2): 15-24

Kvaček, J. (1999b): Two conifers (Taxodiaceae) of the Bohemian Cenomanian (Czech Republic, Central Europe). - In: Stuchlik, L. (ed.), Proceedings of the $5^{\text {th }}$ EPPC (Kraków). Acta Palaeobotanica, Suppl. 2: 129-151.

Kvaček, J. (2014): Cunninghamites johannae, a new cupressoid conifer from the Cenomanian of the Czech Republic and its palaeoecological implications. - Palaeobiodiversity and Palaeoenvironments, 94(2): 377-382. https://doi.org/10.1007/s12549-014-0159-7

Kvaček, J. (2015): Elatocladus velenovskyi a characteristic conifer of the Bohemian Cretaceous Basin. - Palaeontographica, Abteilung B, 92(1-3):79-93. https://doi.org/10.1127/palb/292/2015/79

Kvaček, J., Dašková, J. (2007): Revision of the type material in the genus Nathorstia Heer (Filicales). - Journal of the National Museum (Prague), Natural History Series, 176(7): 117-123.

Kvaček, J., Dašková, J. (2010): Konijnenburgia, a new genus of the fern family Matoniaceae. - Review of Palaeobotany and Palynology, 158(3-4): 308-318. https://doi.org/10.1016/j.revpalbo.2009.10.002

LePage, B. A. (2009): Earliest Occurrence of Taiwania (Cupressaceae) from the Early Cretaceous of Alaska: Evolution, Biogeography, and Paleoecology. - Proceedings of the Academy of Natural Sciences of Philadelphia, 158: 129-158. https://doi.org/10.1635/053.158.0107

Němejc, F. (1968): Paleobotanika III [Palaeobotany III]. Academia, Praha, 474 pp. (in Czech)

Nishida, M., Ohsawa, T., Nishida, H. (1992): Structure and affinities of the petrified plants from the Cretaceous of northern Japan and Saghalian. VIII. Parataiwania nihongii gen. et sp. nov., a taxodiaceous cone from the Upper Cretaceous of Hokkaido. - The Journal of Japanese Botany, 67: 1-9. 
Ohana, T., Kimura, T. (1995): Further observations of Cunninghamiostrobus yubariensis Stopes and Fujii from the Upper Yezo Group (Upper Cretaceous), Hokkaido, Japan. -Transactions and Proceedings of the Palaeontological Society of Japan, 178: 122-141.

Rothwell, G. W., Stockey, R. A., Mapes, G., Hilton, J. (2011): Structure and relationships of the Jurassic conifer seed cone Hughmillerites juddii gen. et comb. nov.: implications for the origin and evolution of Cupressaceae. Review of Palaeobotany and Palynology, 164: 45-59. https://doi.org/10.1016/j.revpalbo.2010.11.004

Schloemer-Jäger, A. (1958): Alttertiäre Pflanzen aus Flözen der Brögger-Halbinsel Spitzbergens. - Palaeontographica, Abteilung B, 104: 39-103.

Schulz, C., Stützel, T. (2007): Evolution of taxodiaceous Cupressaceae (Coniferopsida). - Organisms Diversity \& Evolution, 7: 124-135. https://doi.org/10.1016/j.ode.2006.03.001

Shi, G, Leslie, A. B., Herendeen, P. S., Ichinnorov, N., Takahashi, M., Knopf, P., Crane, P. R. (2014): Whole-plant reconstruction and phylogenetic relationship of Elatides zhoui sp. nov. (Cupressaceae) from the Early Cretaceous of Mongolia. - International Journal of Plant Sciences, 175: 911-930.

https://doi.org/10.1086/677651

Spencer, A. R. T., Mapes, G., Bateman, R. M., Hilton, J., Rothwell, G. W. (2015): Middle Jurassic evidence for the origin of Cupressaceae: a paleobotanical context for the roles of regulatory genetics and development in the evolution of conifer seed cones. - American Journal of Botany, 102: 942-961.

https://doi.org/10.3732/ajb.1500121

Van Konijnenburg-van Cittert, J. H. A., van der Burgh, J. (1989): The flora from the Kimmeridgian (upper Jurassic) of Culgower, Sutherland, Scotland. - Review of Palaeobotany and Palynology, 61(1-2): 1-51. https://doi.org/10.1016/0034-6667(89)90060-2

Zhang, J. W., D’Rozario, A., Wang, L. I., Li, Y., Yao, J. X. (2012): A new species of the extinct genus Austrohamia (Cupressaceae s.1.) in the Daohugou Jurassic flora of China and its phytogeographical implications. - Journal of Systematics and Evolution, 50: 72-82. https://doi.org/10.1111/j.1759-6831.2011.00165.x 